Vol. 7 No. 2 Juli 2018

E-ISSN : 2502-3101 P-ISSN : 2302-528x

http://ojs.unud.ac.id/index.php/jmhu

\title{
Urgensi Kewaspadaan Dini dalam Rangka Memperkuat Persatuan dan Kesatuan Bangsa
}

\author{
I Ketut Rai Setiabudhi ${ }^{1}$, I Gede Artha ${ }^{2}$, I Putu Rasmadi Arsha Putra ${ }^{3}$ \\ ${ }^{1}$ Fakultas Hukum Universitas Udayana, email: raisetiabudhi_fhunud@yahoo.com \\ ${ }^{2}$ Fakultas Hukum Universitas Udayana, email: gedeartha_fhunud@yahoo.com \\ ${ }^{3}$ Fakultas Hukum Universitas Udayana, email: rasmadifh@gmail.com
}

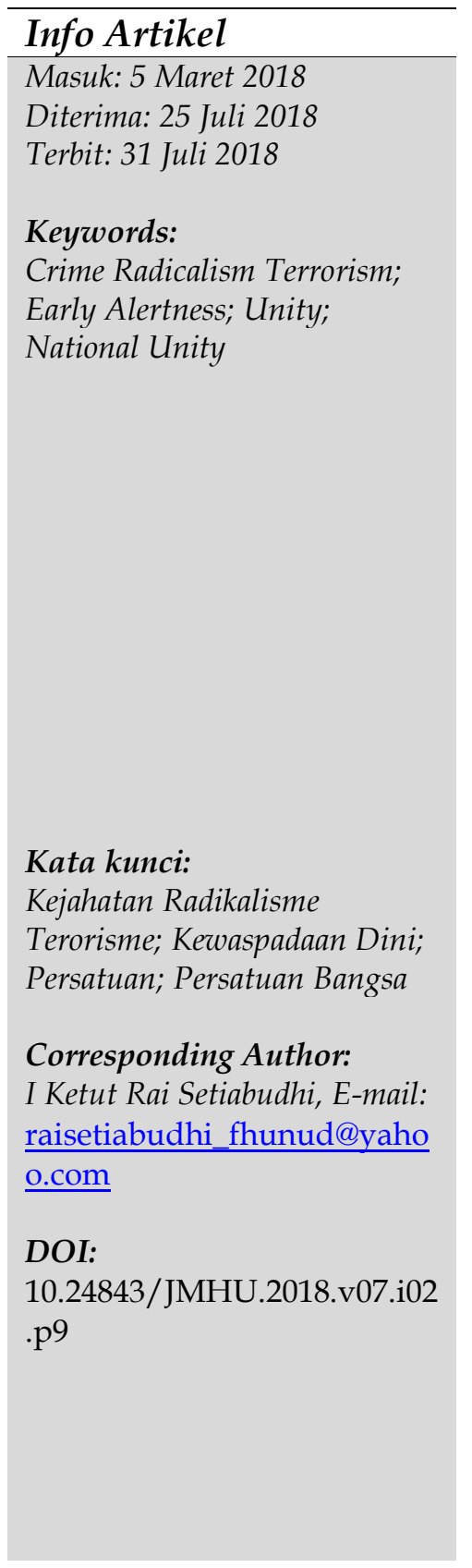

\begin{abstract}
Crime Radicalism-terrorism occurs across nations, involves very large networks, making it very difficult to prevent. Indonesia is one of the country that vulnerable occur radicalism-terrorism. The purpose of this study is to analyze the urgency of the function of the Community Awareness Forum in an attempt to capture or observe emerging symptoms that tend to have indications of harm or damage and disturb public order and peace in society. In addition, it aims to make efforts in conducting early detection of threats that can damage the unity and unity of the Indonesian nation. This research was conducted by using normative legal research supported by empirical data, with statute approach, conceptual approach, and historical approach. The result of the study shows that the Community Awareness Forum strived to work effectively to capture, collect, coordinate and communicate and inform the public about potential security threats, symptoms or catastrophes. The context of early preventive measures can provide recommendations to the government as a government consideration of policies related to public awareness
\end{abstract}

Abstrak
Kejahatan Radikalisme-terorisme terjadi lintas negara,
melibatkan jaringan yang sangat besar, sehingga sangat
sulit dicegah. Indonesia adalah salah satu negara yang
rentan terjadi radikalisme-terorisme. Tujuan studi ini untuk
menganalisa urgensi fungsi Forum Kewaspadaan Dini
Masyarakat dalam upaya menangkap atau mengamati
gejala-gejala yang muncul yang cenderung ada indikasi
membahayakan atau menimbulkan kerugian serta
mengganggu ketertiban dan ketentraman dalam
masyarakat. Selain itu bertujuan menyusun upaya dalam
melakukan deteksi dini terhadap ancaman yang dapat
merusak persatuan dan kesatuan bangsa Indonesia.
Penelitian ini dilakukan dengan menggunakan jenis
penelitian hukum normative yang ditunjang dengan data
empirik, dengan pendekatan the statute approach, conceptual
approach dan historis approach. Hasil studi menunjukkan
bahwa Forum Kewaspadaan Dini Masyarakat diupayakan
berfungsi secara efektif untuk menangkap,


mengumpulkan, mengkoordinasikan dan mengkomunikasikan dan memberi informasi kepada masyarakat tentang potensi ancaman keamanan, gejala atau kejadian bencana. Konteks tindakan pencegahan dini dapat memberikan rekomendasi kepada pemerintah sebagai pertimbangan pemerintah mengenai kebijakan yang berkaitan dengan kesadaran masyarakat.

\section{Pendahuluan}

Indonesia dan negara adi daya seperti Amerika Serikat kerap menjadi sasaran ancaman teroris. Dengan demikian, tampaknya tidak ada di dunia ini suatu negara yang betul-betul aman dari segala ancaman, termasuk bebas dari ancaman terorisme. Amerika Serikat dan negara besar lainnya seperti Perancis justru kerap menjadi sasaran terorisme. Terorisme terjadi lintas negara, melibatkan jaringan yang amat besar serta jenis aksi terror yang satu ini sangat sulit dicegah, bahkan memasuki wilayah kampus. Di Indonesia sendiri paham radikal telah masuk ke berbagai kampus. Bahkan satu kampus di Jawa Barat sempat mendeklarasikan khilafah. Pihak kampus harus bisa mendeteksi dan mencegah jika ada kegiatan-kegiatan yang mengarah ke radikal, jika ada indikasi atau gejala semacam itu, harus cepat dilaporkan ke aparat berwenang. Untuk itu semua perlu waspada apalagi sebagai warganegara Indonesia sangat diperlukan kewaspadaan nasional dan ataupun kewaspadaan dini.

Sejak reformasi banyak sekali persoalan yang muncul kepermukaan, ketika reformasi disikapi secara berlebihan, sosialisasi kewaspadaan nasional dituduh sebagai maneuver pemerintah untuk kembali kepada cara-cara orde baru dalam mengendalikan dunia politik nasional yang bergaya doktriner, sehingga sebagian masyarakat begitu alergi mendengar kewaspadaan nasional yang sejatinya adalah bentuk upaya pemerintah mengajak kehidupan bermasyarakat, berbangsa dan bernegara agar tercipta suasana aman, tertib tenteram dan damai. Ancaman yang dihadapi tidak lagi dalam ranah ideology dan politik saja, akan tetapi sudah masuk dalam ranah yang semakin meluas yang meliputi aspek kehidupan yang menyentuh ranah geografi, demografi, ideology, politik, ekonomi, budaya dan keamanan. Ancaman yang dihadapi tidak lagi ancaman tradisional ataupun konvensional, akan tetapi sudah menggunakan teknologi informasi yang sangat canggih yang begitu cepat dapat mempengaruhi berbagai sendi-sendi kehidupan.

Kementerian Pertahanan Keamanan telah merumuskan hakikat ancaman yang dihadapi oleh bangsa Indonesia di mana disintegrasi persatuan dan kesatuan bangsa adalah ancaman yang perlu mendapat perhatian serius. Di era globalisasi ini, seharusnaya mengartikan ancaman sebagai sebuah kondisi, tindakan yang memiliki potensi baik alamiah maupun hasil rekayasa, yang berbentuk fisik atau non fisik, berasal dari dalam maupun luar negeri, secara langsung maupun tidak langsung diperkirakan atau diduga atau yang sudah nyata yang dapat membahayakan tatanan serta kelangsungan hidup bangsa dan Negara dalam rangka pencapaian tujuan nasional.

Urgensi kewaspadaan nasional dan kewaspadaan dini selain mengantisipasi ancaman teroris dan radikalisme yang sangat membahayakan kesatuan dan persatuan negara, 
namun juga untuk menanggulangi ancaman nya saat ini berupa trauma mendalam. Terorisme tidak hanya menyebabkan banyak korban tetapi juga menyisakan trauma yang mendalam bagi para korban. Siapapun akan merasa terharu dengan cerita para korban terorisme yang masih hidup, mereka harus menanggung derita akibat kerusakan pisik dan psikis yang diderita oleh para korban yang masih selamat yang masih berbekas dan menjadi beban sepanjang hidup. Bahkan tidak sedikit dari mereka yang menderita cacat permanen akibat perbuatan kejam teroris tersebut. Terorisme dapat dikatakan menjadi sebuah tragedi kemanusiaan, terutama bagi para korban. Oleh karena itu, aksi terorisme dapat pula dikatakan suatu bentuk aksi kekerasan (violence) yang dilakukan secara kolektif maupun individual dan dapat dikatakan sebagai kejahatan terhadap kemanusiaan. ${ }^{1}$ Upaya menentang memerangi tindakan radikalisme dan terorisme tak jauh berbeda dalam memerangi kelompok gerilya dengan lawan dan strategi lawan yang tak jelas. ${ }^{2}$ Ganor memberikan pengertian yang beda terhadap terorisme dan gerilya, namun substansi dari kedua aktivitas yang dilakukan keduanya memiliki arah dan tujuan yang sama, yaitu mencapai tujuan politik. ${ }^{3}$ Instabilitas nasional sebagai akibat dari lahirnya gerakangerakan terorisme dan radikalisme memberikan dampak bagi keberlangsungan sosial, ekonomi dan budaya dalam masyarakat. Kejahatan teroris dapat menimbulkan permasalahan seperti kekacauan sosial, ekonomi dan politik dalam masyarakat. ${ }^{4}$

Dengan memperhatikan dampak terorisme dan gerakan radikalisme yang sangat membahayakan negara dan masyarakat, maka sangatlah urgen selalu waspada, yaitu terkait dengan suatu sikap dalam hubungannya dengan nasionalisme yang dibangun dari rasa peduli dan rasa tanggung jawab seseorang warga Negara terhadap kelangsungan kehidupan nasionalnya, kehidupan bermasyarakat, berbangsa dan bernegara dari suatu ancaman. Jadi dituntut adanya suatu kepedulian terhadap kerawanan yang dapat mengancam negara bangsa. Kewaspadaan nasional juga sebagai suatu kualitas kesiapan dan kesiagaan yang harus dimiliki oleh bangsa Indonesia untuk mampu mendeteksi, mengantisipasi sejak dini dan melakukan aksi pencegahan berbagai bentuk dan sifat potensi ancaman Negara Kesatuan Republik Indonesia (NKRI).

Penelitian tentang urgensi kewaspadaan dini dalam rangka memperkuat persatuan dan kesatuan bangsa ini memiliki kajian yang berbeda dengan studi terdahulu yang juga sama-sama mengkaji terorisme dan radikalisme. Beberapa karya ilmiah yang terdahulu yang mengkaji berkaitan dengan kewaspadaan dini dalam rangka memperkuat persatuan dan kesatuan bangsa adalah sebagai berikut; pertama Abdul Syukur tahun 2015 dengan judul Gerakan Dakwah dalam Upaya Pencegahan Dini Terhadap Penyebaran dan Penerimaan Islamisme Kelompok Radikal Terorisme di Lampung yang menjadi fokus kajiannya adalah mengenai peranan gerakan dakwah

1 Armawi, A. (2013). Kajian Penguatan Komunitas Intelijen Daerah. Mimbar Hukum. 25(1). 68-75 https://doi.org/10.22146/jmh.16110

2 Prajarto, N. (2004). Terorisme dan media massa: Debat keterlibatan media. Jurnal Ilmu Sosial dan Ilmu Politik, 8(1), 37-52 doi.org/10.22146/jsp.11057

${ }^{3}$ Ganor, B. (2002). Defining terrorism: Is one man's terrorist another man's freedom fighter? Police Practice and Research. 3(4). 287-304 https:// doi.0rg/10.1080/1561426022000032060

${ }^{4}$ Muin, F., \& Aspihanto, A. (2017). Sinergi Terhadap Pencegahan Terorisme dan Paham Radikalisme. Seminar Nasional Hukum Universitas Negeri Semarang. 3(1). $\quad$ 73-90 https://journal.unnes.ac.id/sju/index.php/snh/article/view/20923 
sebagai upaya pencegahan dini terhadap penyebaran islamisme kelompok radikal di lampung dalam mempertahankan kesatuan dan kesatuan bangsa. ${ }^{5}$ Kedua oleh Achmadudin Rajab tahun 2016 dengan judul Urgensi Penguatan Badan Nasional Penanggulangan Terorisme (BNPT) dalam Rangka Menjaga Keamanan dan Kedaulatan Negara yang menjadi pokok bahasannya adalah Urgensi penguatan Badan Nasional Penanggulangan Terorisme (BNPT) dalam upaya melakukan penegakan hukum dalam rangka menjaga keamanan dan kedaulatan Negara dari ancaman terorisme. ${ }^{6}$

Tujuan Penelitian ini adalah untuk memahami serta menganalisa Urgensi fungsi Forum Kewaspadaan Dini Masyarakat dalam upaya untuk menangkap atau mengamati gejala-gejala yang muncul yang cenderung ada indikasi membahayakan atau menimbulkan kerugian sehingga perlu diwaspadai agar tidak sampai terjadi halhal yang tidak diharapkan yang dapat mengganggu ketertiban dan ketentraman dalam masyarakat. Selain itu juga untuk mengetahui dan menyusun upaya apa yang dilakukan agar Forum Kewaspadaan Dini Masyarakat, seperti di Bali lebih berhasil dan berdaya guna dalam melakukan deteksi dini terhadap ancaman yang dapat merusak persatuan dan kesatuan bangsa Indonesia.

\section{Metode Penelitian}

Metode penelitian merupakan hal yang amat penting dalam melakukan kajian ilmiah. Penelitian ini dilakukan dengan menggunakan jenis penelitian hukum normatif serta ditunjang dengan penelitian empirik. Menurut Soerjono Soekanto dan Sri Mamudji penelitian hukum normatif juga dikenal dengan sebutan penelitian kepustakaan ${ }^{7}$. Dalam studi ini fokus utamanya pengkajiannya dari aspek normanya, namun untuk melengkapi ditunjang dengan melihat dari aspek empirisnya, yaitu apa yang telah dilakukan oleh masyarakat (melalui Forum Deteksi Dini) untuk melakukan deteksi dini. Pendekatan yang digunakan adalah pendekatan undang-undang (the statute approach), pendekatan konsep (conceptual approach), dan pendekatan sejarah (historis approach). Pendekatan undang-undang, pengkajiannya didasarkan pada peraturan perundang-undangan. Dalam pendekatan ini perlu dipahami hierarki dan asas-asas dari peraturan perundang-undangan yang dipakai 8 . Undang-undang yang dipergunakan adalah Norma (dasar) atau kaidah dasar, yaitu:

1. Pembukaan Undang-undang Dasar 1945;

2. Peraturan dasar: Batang Tubuh UUD 1945; Ketetapan-ketetapan MPR;

3. Peraturan perundang-undangan: undang-undang dan peraturan yang setaraf; keputusan menteri dan keputusan yang setaraf Yurisprudensi. ${ }^{9}$ Seperti misalnya Undang-undang Nomor 15 Tahun 2003 tentang Penetapan Peraturan pemerintah Pengganti Undang-undang Nomor 1 Tahun 2002 tentang Pemberantasan Tindak Pidana Terorisme menjadi Undang-undang (Lembaran Negara Republik Indonesia

\footnotetext{
${ }^{5}$ Syukur, A. (2017). Gerakan Dakwah Dalam Upaya Pencegahan Dini Terhadap Penyebaran Dan Penerimaan Islamisme Kelompok Radikal-Terorisme Di Lampung. Analisis: Jurnal Studi Keislaman. 15(1). 219-250

${ }^{6}$ Rajab, A. (2016). Urgensi Penguatan BNPT dalam Rangka Menjaga Keamanan dan Kedaulatan Negara. Jurnal RechtsVinding. 5(1).

7 Soekanto, S. \& Mamudji, S. (2004). Penelitian Hukum Normatif. Rajawali Pers. Jakarta. h.13-14.

8 Marzuki, P. M. (2005). Penelitian Hukum. Prenada Media. Jakarta. h. 96

9Soekanto, S. \& Mamudji, M. Op.Cit. h. 12
} 
Tahun 2003 Nomor 45, Tambahan Lembaran Negara Republik Indonesia Nomor 4284); Peraturan Menteri Dalam Negeri Nomor 12 Tahun 2006 tentang Deteksi Dini, dan lain-lain.

Selain itu, juga dipergunakan pendekatan konsep untuk dapat memahami dengan benar secara logika konsep-konsep yang dipergunakan dalam penelitian ini. Seperti konsep tentang kewaspadaan, kerawanan, ancaman, gangguan, dan lain-lain. Pendekatan sejarah dipergunakan untuk melihat pengalaman-pengalaman pada masa lalu yaitu sejak proklamasi, masa orde lama, masa orde baru, sampai dengan masa reformasi, dimana banyak sekali pengalaman yang dihadapi oleh bangsa kita, yang mana kalau tidak cepat dilakukan antisipasi dan diatasi secara tepat akan sangat membahayakan bagi kelangsungan persatuan dan kesatuan bangsa yang kita cintai ini. Teknik analisis data maupun bahan hukum dilakukan dengan teknik deskripsi, sistematisasi, dan eksplanasi sebagai aspek epistemologi dalam penelitian ini. Pada tahap deskripsi dilakukan langkah-langkah untuk menentukan isi atau makna dari aturan hukum. Langkah sistematisasi dilakukan untuk memaparkan isi dan struktur atau hubungan hierarkis antara aturan-aturan hukum yang digunakan sebagai dasar untuk menganalisis permasalahan dalam penelitian ini. Pada tahap eksplanasi, dilakukan penjelasan dan analisis.

\section{Hasil dan Pembahasan}

\subsection{Hakikat Kewaspadaan dan Kerawanan}

Manusia sebagai mahluk Tuhan dikaruniai kemampuan yang sangat berharga, yaitu akal budi dan kehendak yang dinamis. Akal budi atau juga disebut intelek adalah kemampuan untuk melihat sesuatu sebagai yang benar dan tepat, sedangkan kehendak yang dinamis adalah kemampuan untuk memilih sesuatu sebagai yang baik bagi dirinya.

Kewaspadaan merupakan aktual kemampuan intelektual manusia, sehingga manusia dengan sadar menentukan sikapnya terhadap masalah yang dihadapi dan mengambil keputusan sebagai pilihannya yang baik dan benar. Dengan demikian kewaspadaan (nasional) berarti kesadaran dan kesiagaan bangsa untuk melihat dengan tajam dan teliti masalah yang dihadapi secara nasional, baik dalam bentuk kerawanan maupun dalam bentuk ancaman, gangguan, hambatan, ataupun tantangan, serta mampu menemukan peluang yang terbuka sehingga dapat mengambil sikap dan keputusan yang benar dan baik bagi keselamatan, kelestarian, dan kepentingan bangsa dan Negara untuk membangun dirinya dengan menciptakan kondisi yang melibatkan segala aspek kehidupan bangsa, dan dengan demikian membentuk dan memiliki suatu kekuatan yang riil dan efektif, yang berupa kemampuan dan ketangguhan bangsa untuk dimanfaatkan sebaik-baiknya. Kewaspadaan nasional saat ini adalah hal yang penting mengingat pemerintah dan warga negara harus memahami jati dirinya sebagai bangsa Indonesia. Kewaspadaan nasional memiliki arti kualitas kesiapan, kesiapsiagaan serta manifestasi kepedulian dan rasa tanggung jawab bangsa Indonesia untuk mampu mendeteksi, mengantisipasi sejak dini dan melakukan pencegahan berbagai bentuk ancaman. Kewaspadaan nasional adalah suatu sikap dalam hubungan dengan nasionalisme yang dibangun dari rasa peduli dan rasa tanggung jawab serta perhatian warga negara terhadap kelangsungan kehidupan bermasyarakat, berbangsa, dan bernegara. Selain itu, kewaspadaan nasional juga dapat diartikan sebagai 
manifestasi kepedulian dan rasa tanggung jawab bangsa Indonesia terhadap keselamatan dan kedudukan bangsa dan negara kesatuan Indonesia. ${ }^{10}$

Konsep kerawanan pada hakikatnya merupakan kelemahan yang terdapat dalam kehidupan masyarakat baik dalam arti fisik maupun mental. Titik-titik kerawanan bias disebabkan oleh kondisi manusia dan alam yang terbatas dan serba kekurangan, bias juga oleh tingkah laku bangsa yang menelantarkan peri kehidupan sosial ekonominya di tengah-tengah kondisi dan proses perkembangan zaman sehingga menjadi bangsa yang mundur. Selain itu konteks sosial budaya yang melatarbelakangi kehidupan bangsa mampu memperjelas dan mempertajam sorotan terhadap titik-titik rawan yang ada. Munculnya kerawanan memiliki potensi yang berbeda, dapat bersifat biasa, namun juga dapat berakibat terganggunya stabilitas keamanan dalam negeri apabila tidak dilakukan langkah-langkah antisipasi sedini mungkin. ${ }^{11}$

Oleh karena itu, dalam membahas kerawanan bukan saja diperlukan ketelitian observasi, melainkan terutama pengenalan diri, yaitu dengan mengadakan introspeksi. Usaha mawas diri ini membutuhkan bukan sekadar penalaran dalam mengindentifikasi titik-titik lemah yang terdapat dalam masyarakat, melainkan juga kepekaan moral yang mendorong kita berani mengakui kelemahan-kelemahan yang kita lakukan sendiri, tanpa mengurangi kebanggaan dan harga diri sebagai bangsa yang merdeka, mandiri dan andal. Kurang perhatian terhadap kerawanan yang dimiliki bangsa berarti membiarkan bangsa telanjang bagi dunia luar, dan menjadi sasaran keinginannya dan seakan-akan pasrah terhadap eksploitasi pihak-pihak luar. Kelalaian dalam menangani dan member proteksi terhadap titik-titik kerawanan bangsa berarti membuka pintu gerbang keberadaan kita menjadi terbuka lebar terhadap penetrasi kekuatan-kekuatan asing yang ingin memanfaatkan kondisi bangsa. Bilamana kita kurang memperhatikan kerawanan maka peluang akan bisa berkembang menuju pelemahan terhadap persatuan dan kesatuan bangsa.

\subsection{Kewaspadaan Terhadap Dampak Radikalisme-Terorisme}

Kewaspadaan yang harus mendapat perhatian serius, karena selain menimbulkan dampak langsung maupun tidak terorisme dengan faham radikalismenya merupakan ancaman yang membahayakan tidak hanya bagi masyarakat maupun pribadi dan keluarga korban, tetapi juga bagi Negara.

Muladi memberi catatan bahwa hakikat perbuatan terorisme mengandung perbuatan kekerasan atau ancaman kekerasan yang berkarakter politik. Bentuk perbuatan bisa berupa perompakan, pembajakan maupun penyanderaan. Pelaku dapat merupakan individu, kelompok, atau negara. Sedangkan hasil yang diharapkan adalah munculnya rasa takut, pemerasan, perubahan radikal politik, tuntutan hak asasi manusia, dan

\footnotetext{
${ }^{10}$ Hikam, M. A. (2016). Pendidikan Multikultural dalam Rangka Memperkuat Kewaspadaan Nasional Menghadapi Ancaman Radikalisme di Indonesia. Global: Jurnal Politik Internasional. 17(1). 1-17 https://doi.org/10.7454/global.v17i1.26

${ }^{11}$ Sulistiono, I (2015) Peran Intelijen Keamanan dalam Melakukan Deteksi Dini Terhadap Perkembangan Gangguan Kamtibmas (Studi terhadap Penyelenggaraan Pilkada Di Kabupaten Ketapang tahun 2015). Jurnal nestor Magister Hukum, 1(1).
} 
kebebasan dasar untuk pihak yang tidak bersalah serta kepuasan tuntutan politik lain. ${ }^{12}$

Berbagai dampak yang ditimbulkan oleh kelompok radikal maupun teroris terhadap Negara adalah:

1. Dampak terhadap ideologi. Terorisme sanga bertentangan dengan ideologi Pancasila, yang sangat bertentangan dengan kelima silanya terutama prinsip ketuhanan dan kemanusiaan, karena gerakannya tidak pandang bulu, mengorbankan orang-orang yang tidak bersalah yang tidak tahu apa-apa, dari anak-anak, dewasa, orang tua, laki-laki maupun wanita. Dengan di serangnya ideologi tentu akan membuat berantakan rasa persatuan dan kesatuan bangsa;

2. Dampak terhadap agama, terorisme dengan sepihak mengklaim membela saudarasaudara seagamanya, justru mempermalukan agama itu sendiri. Berapa banyak Negara dengan basis mayoritas muslim yang telah dicurigai dunia internasional sebagai sarang teroris. Berapa banyak umat Islam yang dengan ciri tertentu telah dicurigai sebagai teroris. Berapa banyak organisasi Islam yang tidak ada hubungannya dengan kelompok teroris tetapi mendapat kesan yang kurang baik akibat perbuatan teror;

3. Dampak terhadap politik, beragam aksi teroris baik besar maupun kecil di tanah air telah banyak memberikan dampak politik bagi Indonesia dalam pergaulan internasional. Citra Indonesia sebagai Negara yang tidak aman semakin tidak terhindarkan. Padahal butuh beberapa tahun untuk meyakinkan dunia internasional tentang keamanan dalam negeri yang dalam waktu sekejap diruntuhkan oleh aksi teroris;

4. Dampak terhadap ekonomi, sangat jelas aksi terorisme telah berdampak buruk bagi ekonomi nasional. Tidak hanya bagi persoalan investasi besar yang mulai ragu ketika ada kejadian terorisme, pelaku ekonomi menengah ke bawah yang mengandalkan dunia pariwisata terganggu karena ketidakamanan yang ditimbulkan oleh aksi terorisme;

5. Dampak terhadap kedaulatan dan pertahanan, aksi terorisme yang terjadi seakan ingin menceraikan antara pemerintah dengan warganya. Ketika terorisme terjadi, tidak hanya persoalan keamanan tetapi kedaulatan Negara diusahakan untuk diruntuhkan oleh para teroris dengan cara menanamkan ketidakpercayaan masyarakat terhadap pemerintah. ${ }^{13}$

Demikian masifnya dampak dari terorisme dengan pahamnya yang radikal terhadap Negara dan masyarakat, maka diperlukan kewaspadaan terkait dengan sikap nasionalisme yang terbangun dari rasa peduli dan rasa tanggung jawab seseorang warga Negara terhadap kelangsungan nasionalnya, kehidupan bermasyarakat, berbangsa dan bernegara dari suatu ancaman. Jadi sangat urgen suatu kewaspadaan terhadap ancaman-ancaman yang bersifat terorisme dan yang berbau radikalisme. Dalam menjaga kesatuan dan persatuan Negara Kesatuan Republik Indonesia (NKRI) maka diperlukan suatu kepedulian terhadap suatu kerawanan-kerawanan yang dapat mengancam. Tingginya tingkat kewaspadaan nasional juga sebagai suatu tolak

12 Muladi, M. (2012). Hakekat Terorisme dan Beberapa Prinsip Pengaturan dalam Kriminalisasi. Jurnal Kriminologi Indonesia. 2(3).

${ }^{13}$ Saifullah, S. (2015). Mengenal, Mewaspadai Mencegah Radikalisme dan Terorisme. Tanpa Penerbit. Forum Koordinasi Pencegahan Terorisme (FKPT) Sumatera Barat. h. 9 
kualitas kesiapan dan kesiagaan suatu bangsa untuk mampu mendeteksi, mengantisipasi sejak dini dan mampu melakukan pencegahan berbagai bentuk dan sifat potensi ancaman terhadap Negara Kesatuan Republik Indonesia (NKRI).

\subsection{Kewaspadaan Terhadap Ancaman Pancasila}

Suatu rahmat yang harus dan amat kita syukuri kepada Tuhan Yang Maha Esa, kita memiliki Pancasila sebagai pandangan hidup dasar Negara maupun sebagai kepribadian bangsa, sehingga bangsa Indonesia tidak mudah terombang-ambing dalam era globalisasi keterbukaan saat ini. Dengan landasan tersebut bangsa Indonesia yang beragam multi kultur dapat hidup bersama, rukun bersatu dan membangun masa depan dengan kesadaran sebagai suatu bangsa, satu tanah air dan satu bahasa, yaitu Indonesia. Walaupun demikian bangsa kita tidak luput dari berbagai kerawanan yang harus senantiasa diwaspadai. Karena Pancasila merupakan nilai-nilai dasar kehidupan bermasyarakat, berbangsa dan bernegara dengan memberikan pijakanpijakan yang mantap, orientasi ke depan yang memberi cakrawala yang luas dan menumbuhkan etos kerja yang tinggi maka titik-titik kerawanan dapat ditemukan dalam persepsi mentalitas politik ideologi dengan sikap-sikap yang mengganggu bahkan mengancam mau mengganti Pancasila itu sendiri. Seperti Radikalismeterorisme.

Berdasarkan hasil survey nasional tentang daya tangkal masyarakat terhadap radikalisme, ditemukan hasil bahwa potensi radikalisme di Bali tahun 2017 menunjukkan angka yang perlu diwaspadai yaitu 52,5 pada rentang 0 sampai dengan 100. Angka ini menunjukkan bahwa tingkat potensi radikalisme tersebut berada pada kategori 'potensi sedang'. Potensi radikal tertinggi dicerminkan oleh factor dominan dari potensi sikap radikal yang berada pada angka 31,821 (potensi kuat) dan potensi pemahaman radikal pada angka 15,972 (potensi sedang). Sikap radikal tidak selalu dan tidak mesti terimplementasi dengan aksi kekerasan.

Berbagai kerawanan yang secara prinsip tidak sesuai dengan nilai-nilai Pancasila yang perlu diwaspadai, antara lain:

1. Komunisme, pelopor utama yang mengajarkan komunisme adalah Karl Marx (18181883), pemikir sosialisme radikal yang banyak menulis naskah di bidang sosial dan ekonomi. Ajaran Marx yang disebut Marxisme dikembangkan oleh Lenin menjadi marxisme-leninisme, yang kemudian oleh Stalin dijadikan dasar ideologi Negara komunis. Dengan demikian, Marxisme-leninisme adalah Komunisme. Pokok-pokok ajaran Komunisme yang bertentangan dengan Pancasila, antara lain, dapat disebutkan sebagai berikut bahwa,

a. Ajaran komunisme bersifat atheis. Ajaran komunisme didasarkan atas kebendaan, maka komunisme tidak percaya kepada adanya Tuhan. Bahkan, agama dikatakannya sebagai racun bagi masyarakat. Ajaran tersebut jelas bertolak belakang dengan Pancasila. Dengan Ketuhanan Yang Maha Esa, bangsa Indonesia menyatakan kepercayaan dan ketakwaannya terhadap Tuhan Yang maha Esa.

b. Komunisme adalah Internasionalisme. Pada prinsipnya masyarakat Komunis adalah masyarakat komunis dunia yang tidak dibatasi oleh kesadaran nasional. Hal ini tercermin dari seruan Marx yang sangat terkenal 'kaum buruh di seluruh dunia, bersatulah'! Komunisme juga menghendaki masyarakat tanpa nasionalisme. Hal ini bertentangan dengan Pancasila. 
2. Ekstrimisme, yaitu paham, kecenderungan atau watak yang sangat kuat terhadap suatu pandangan, keyakinan yang melampaui batas kebiasaan, terutama dalam hal politik, misalnya ada ekstrimisme sayap kiri dan sayap kanan. Lawan dari istilah ini adalah pandangan moderat, jalan tengah. Istilah ini merujuk pada pemahaman atau keyakinan, sehingga muncul istilah pandangan ekstrim, keyakinan ekstrim dan pemahaman ekstrim ${ }^{14}$.

3. Ekstrim orang atau kelopok yang menganjurkan atau mengambil langkah di luar norma atau kebiasaan umum, terutama di bidang politik. Ekstrim berarti orang yang memegang ekstrimisme ${ }^{15}$

4. Radikalisme, berasal dari bahasa latin, 'radix' yang berarti 'akar', istilah yang digunakan pada akhir abad 18 di Barat untuk merujuk cita-cita, ide dan gagasan pendukung gerakan yang menuntut perubahan yang mendasar;

5. Radikalisasi, proses di mana seorang individu atau kelompok mulai mengadopsi cita-cita dan aspirasi politik, sosial atau agama yang ekstrim. Radikalisasi bisa pula diartikan sebagai proses lanjutan dari ektrimisme yakni perubahan dari pandangan moderat atau pandangan umum ke arah pandangan ekstrim. Ketika seseorang menjalani radikalisasi tersebut ia akan memunculkan sikap dan gerakan radikal. Jadi gerakan radikal itu merujuk pada suatu pola pemahaman dan tindakan yang menginginkan suatu perubahan yang mendasar dengan cara ekstrim, yang menolak kebiasaan atau norma-norma yang berlaku;

6. Kelompok radikal gagasan, kelompok ini gencar mengemukakan gagasan, ide dan pikiran yang radikal dan ekstrim, baik terkait isu politik, ekonomi maupun keagamaan yang berbeda dengan pandangan kebanyakan. Walaupun kelompok ini tidak terlibat langsung dalam aksi kekerasan, kelompok ini juga berbahaya karena gagasan-gagasannya yang radikal dan ekstrim, misalnya ingin merubah dasar Negara Pancasila dengan ideology yang lain, yang disampaikan baik melalui tulisan atau lisan di mimbar yang sangat mengancam wawasan kehidupan bermasyarakat, berbangsa dan bernegara.

7. Kelompok radikal kekerasan non-terorisme, kelompok ini radikal secara tindakan dalam wujud aksi kekerasan atau kelompok kekerasan yang mengatasnamakan agama dengan melakukan intimidasi, kekerasan fisik dan ataupun perusakan terhadap fisik. Kelompok ini sangat berbahaya karena sangat mengganggu ketertiban dan keamanan masyarakat. Mereka cenderung merusak hubungan toleransi dan kerukunan antar masyarakat yang berbeda agama;

8. Kelompok radikal milisi, yaitu gerakan dalam bentuk milisi yang terlibat dalam konflik komunal, seperti laskar jihad, laskar mujahidin, dan lain-lain. layaknya tentara, mereka dilengkapi dengan persenjataan yang dating dengan alasan membantu menyelesaikan masalah, namun dapat memperkeruh suasana di wilayah konflik;

9. Kelompok radikal separatis, kelompok ini merupakan gerakan separatis yang terorganisir dan mengusung misi separatis atau pemisahan diri dari Negara. Contoh gerakan ini misalnya kelompok radikal NII,GAM, OPM, dan RMS. Tentu saja gerakan ini berbahaya untuk kesatuan dan kesatuan bangsa16

\footnotetext{
14 Malik. A. (2014). Diary Perdamaian, mengenal, mewaspadai dan mencegah terorisme di kalangan Generasi muda. Badan Nasional Penaggulangan Teroris. Jakarta. h. 8

${ }^{15}$ Ibid.

${ }^{16}$ Saifullah, S. Op.Cit. h. 3
} 
10.Kelompok radikal terorisme, yaitu kelompok yang menafsirkan suatu ideology atau ajaran keagamaan secara salah melalui pemahaman yang ekstrim dan mewujudkan dalam aksi terror dan kekerasan

11.Kelompok radikal lainnya, kelompok yang menyuarakan kepentingannya secara radikal dan ekstrim baik dalam isu politik, sosial, budaya, ekonomi, dll.

Ancaman serius yang harus dihadapi dan selalu diwaspadai dewasa ini adalah kelompok terorisme, kelompok ini dapat diartikan sebagai tindakan atau ancaman kekerasan dengan tujuan politik tertentu dengan cara menciptakan kepanikan dan ketakutan di tengah-tengah masyarakat dengan sasaran dan target kepada siapa pun dan dimanapun berada yang dilakukan oleh kelompok yang terorganisasi rapi, mempunyai kader militant dengan disiplin tinggi dan jaringan kuat lintas Negara. Oleh karena itu terorisme musuh semua kalangan yang memimpikan dan mencitacitakan perdamaian. Terorisme merupakan musuh Negara yang menyerang kedaulatan Negara dan keamanan masyarakat. Seluruh komponen bangsa harus terpanggil dalam upaya pencegahan terorisme. Terorisme merupakan musuh semua agama karena tidak ada satu pun agama yang mengajarkan kekerasan, kebrutalan. Terorisme tidak berkaitan dengan pemeluk agama tertentu karena dilakukan tidak berdasarkan ajaran agama, karena terorisme itu musuh keamanan dan perdamaian, musuh semua manusia, maka pemberantasan tindak pidana terorisme harus dilakukan secara komprehensif. ${ }^{17}$

\subsection{Kewaspadaan Terhadap Ancaman bagi Undang-undang Dasar Negara Republik Indonesia 1945}

Hukum diciptakan untuk mengatur kehidupan masyarakat agar berlangsung segala sesuatunya dengan lancar, adil, tertib dan aman. Dalam system hokum nasional nilainilai yang terdapat dalam ideologi dan dasar Negara Pancasila dijelmakan wujud konkritnya dalam Undang-undang Dasar Negara 1945 sebagai sumber hukum tertinggi dari hokum yang berlaku di Indonesia. Sebagai Negara hukum yang telah tercantum dalam Undang-undang Dasar, maka setiap warganegara wajib untuk mentaatinya segala peraturan perundang-undangan yang menjadi turunannya sampai aturannya yang paling bawah. Bukan saja wajib dan bertekad untuk mentaatinya apa yang tersurat dalam pasal-pasalnya, melainkan juga bertekad untuk melaksanakannya secara jujur dan adil apa yang tersirat atau apa yang terdapat dalam suasana kebatinan yang tidak lain adalah nilai-nilai Pancasila.

Penyimpangan atau pertentangan dengan ketentuan UUD NKRI 1945, serta suasana kebatinan ideologi Pancasila yang mengatur tata hubungan antara lembaga-lembaga Negara, atau antara kelompok atau anggota masyarakat, akan dapat menimbulkan kerawanan berupa ancaman terhadap ketertiban dan keamanan masyarakat bangsa dan Negara. Oleh karena itu kita semua perlu waspada terutama para penyelenggara Negara, pemimpin supra maupun infra struktur politik, demikian pula setiap warganegara, hendaknya selalu memiliki kewaspadaan dini yang tinggi agar kondisi semacam itu dapat dicegah lebih awal.

${ }^{17} J a z u l i$, A. (2017). Strategi Pencegahan Radikalisme dalam Rangka Pemberantasan Tindak Pidana Terorisme (Prevention Strategy of Radicalism in Order To Wipe Out The Terrorism $\begin{array}{lllll}\text { Crime). Jurnal Ilmiah } & \text { Kebijakan Hukum, 10(2), } & 197\end{array}$ http:/dx.doi.org/10.30641/kebijakan.2016.V10.197-209 
Kewaspadaan dalam rangka menegakkan UUDN RI 1945, berarti meneliti sejauh mana terdapat kerawanan-kerawanan dalam melakukan pola hubungan dan interaksi sosial masyarakat multi kultural. Dan tentu akan sangat berbahaya bilamana kerawanankerawanan tersebut dibiarkan tanpa ada daya tangkal yang harus dilakukan.

Semangat dari kebijakan negara untuk menghadapi timbulnya kerawanan yang dapat mengganggu stabilitas negara. Pemerintah Indonesia telah mengeluarkan enam prinsip-prinsip umum dan kerangka kerja dalam menghadapi aksi terror. Badan Nasional Penanggulangan Teororisme (BNPT) merumuskan prinsip dasar kebijakan anti terorisme: (1) Supremasi hukum, yaitu penggunaan kerangka hukum selalu menjadi basis pedoman dari aksi kontra teror. (2) Indiskriminasi, berarti dalam upaya kontra teror, Pemerintah Indonesia tidak akan menuduh dan hanya memfokuskan pada satu kelompok saja, baik itu kelompok etnis, agama maupun kepentingan. (3) Prinsip independensi, yaitu sifat bebas dalam membuat kesimpulan dan mengambil tindakan, rekomendasi ataupun harapan masyarakat Internasional diposisikan sebagai masukan dan pertimbangan. ${ }^{18}$

\subsection{Deteksi Dini Terhadap Kerawanan yang Terjadi Dalam Masyarakat}

Munculnya terorisme oleh kelompok minoritas maupun oleh negara adalah tidak dihargainya nilai-nilai demokrasi maupun nilai-nilai kemanusiaan. Dengan demikian usaha pencegahan terorisme yang efektif adalah usaha untuk menghidupkan dan melaksanakan nilai-nilai demokrasi dan nilai-nilai kemanusiaan di masyarakat. Mengantisipasi terorisme yang dilakukan oleh kelompok minoritas relatif mudah, sebab perasaan ketidakpuasan dari kelompok minoritas ini tidak secara serta merta akan diwujudkan dalam bentuk tindakan pemaksaan kehendak. Bila suatu kelompok militan terbentuk, maka sifat ekslusif dari kelompok menjadi menonjol. Kendatipun eksklusifitas belum tentu menghasilkan radikalisme, namun sebagai cikal bakal radikalisme sesungguhnya akan dapat diidentifikasi oleh masyarakat sekitarnya. ${ }^{19}$

Berdasarkan Peraturan Menteri Dalam Negeri Nomor 12 Tahun 2006 tentang Kewaspadaan Dini Masyarakat di Daerah, yang di dasarkan atas pertimbangan untuk mewujudkan ketenteraman, ketertiban dan perlindungan masyarakat, maka perlu dilakukan upaya-upaya kewaspadaan dini oleh masyarakat itu sendiri. Kewaspadaan dini masyarakat adalah kondisi kepekaan, kesiagaan dan antisipasi masyarakat dalam menghadapi potensi dan indikasi timbulnya bencana, baik bencana perang, bencana alam, maupun bencana karena ulah manusia, sudah tentu terkait dengan ini pula kewaspadaan dini terhadap munculnya kelompok-kelompok radikalisme ataupun terorisme.

Penyelenggaraan kewaspadaan dini masyarakat sudah diatur pada BAB II Peraturan Menteri Dalam Negeri Nomor 12 Tahun 2006 tentang Kewaspadaan Dini Masyarakat di Daerah, dimana kewaspadaan dini masyarakat menjadi tanggungjawab dan

${ }^{18}$ Mukhtar, S. (2016). Strategi Pemerintah Indonesia Menghadapi Terorisme dalam Era Demokratisasi. Reformasi. 6(2).

${ }^{19}$ Mustofa, M. (2012). Memahami Terorisme: Suatu Perspektif Kriminologi. Jurnal Kriminologi Indonesia. 2(3). 
dilaksanakan oleh masyarakat yang difasilitasi dan dibina oleh pemerintah provinsi, kabupaten/kota, kecamatan sama ke tingkat desa dengan tugas-tugas yang meliputi:

1. Membina dan memelihara ketenteraman, ketertiban dan perlindungan masyarakat dalam menghadapi kemungkinan terjadinya bencana;

2. Mengkoordinasikan dalam penyelenggaraan kewaspadaan dini masyarakat;

3. Mengkoordinasikan kegiatan instansi vertical dalam penyelenggaraan kewaspadaan dini masyarakat.

Masing-masing memiliki tugas dan kewajiban sesuai dengan cakupan wilayahnya. Seperti tugas dan kewajiban kepala desa/lurah dalam kaitan dengan diteksi dini ini antara lain meliputi:

1. Membina dan memelihara ketenteraman dan ketertiban dan perlindungan masyarakat dalam menghadapi kemungkinan terjadinya bencana, baik bencana perang, bencana alam maupun bencana karena ulah manusia termasuk dalam hal ini kewaspadaan akan radikalisme maupun terorisme;

2. Mengkoordinasikan tokoh masyarakat, tokoh adat, tokoh agama, tokoh pemuda, anggota satlinmas, anggota Polmas dan elemen masyarakat lainnya dalam kegiatan di bidang ketenteraman, ketertiban dan perlindungan masyarakat, dengan meningkatkan kewaspadaan dini masyarakat terutama di tingkat desa dan maupun kelurahan.

Dalam upaya untuk dapat melaksanakan tugas-tugas tersebut secara lebih efektif dan efisien, sesuai dengan arahan Peraturan Menteri tersebut maka di masing-masing wilayah provinsi, kabupaten/kota, kecamatan, dan sampai ke desa dibentuk lah Forum Kewaspadaan Dini Masyarakat (FKDM). Pembentukan FKDM dilakukan oleh masyarakat sendiri dan difasilitasi oleh pemerintah daerah. Pada prinsipnya keanggotaan FKDM baik di tingkat propinsi, kabupaten/kota, kecamatan maupun desa/kelurahan terdiri atas wakil-wakil ormas, perguruan tinggi, lembaga pendidikan lain, tokoh masyarakat, tokoh adat, tokoh agama, tokoh pemuda, dan elemen masyarakat lainnya, dan khusus di tingkat desa/kelurahan ditambah dengan anggota satlinmas dan anggota Polmas.

Adapun tugas dari FKDM di tingkat provinsi adalah untuk menjaring, menampung, mengkoordinasikan dan mengkomunikasikan data dan informasi dari masyarakat mengenal potensi ancaman keamanan, gejala atau peristiwa bencana dalam rangka upaya pencegahan dan penaggulangan secara dini; dan memberikan rekomendasi sebagai bahan pertimbangan gubernur mengenai kebijakan yang berkaitan dengan kewaspadaan dini masyarakat. FKDM kabupaten/kota mempunyai tugas untuk menjaring, menampung, mengkoordinasikan, dan mengkomunikasikan data dan informasi dari masyarakat mengenal potensi ancaman keamanan, gejala atau peristiwa bencana dalam rangka upaya pencegahan dan penaggulangannya secara dini; dan memberikan rekomendasi sebagai bahan pertimbangan bagi bupati/wali kota mengenai kebijakan yang berkaitan dengan kewaspadaan dini masyarakat. Demikian pula tugas FKDM di tingkat kecamatan maupun di tingkat desa/kelurahan mempunyai tugas yang serupa sesuai dengan bidang tingkatannya masing-masing wilayah kecamatan maupun desa/kelurahan. 
Beberapa kerawanan yang terdapat dalam masyarakat yang perlu mendapatkan perhatian serius dan perlu usaha yang sungguh-sungguh untuk dapat mengatasinya, adapun kerawanan tersebut antara lain:

1. Kemiskinan, kemiskinan baik dalam arti absolute maupun dalam arti relative selalu merupakan lahan tumbuhnya ketidakpuasan serta kegelisahan masyarakat. Oleh karena itu masalah yang sedang menghadapi masalah ini selalu peka terhadap janjijanji yang memberikan harapan dan mudah mengikuti jalan keluar yang ditawarkan kepadanya oleh unsur-unsur yang bertanggungjawab tanpa memperhatikan motivasi ideologis yang melatarbelakanginya. Keputusasaan mudah mendorong mereka terkena hasutan untuk melakukan tindakan-tindakan radikal yang merugikan kepentingan masyarakat dan dapat meniadakan arti hasil pembangunan. Kemiskinan ditenggarai sebagai peningkatan kudeta politik, perang saudara, dan aksi-aksi kekerasan seperti terorisme. ${ }^{20}$ Bahkan Michael Moore Presiden WTO mengatakan bahwa kemiskinan dalam segala bentuknya merupakan sebuah ancaman terbesar dan satu-satunya bagi perdamaian, keamanan, demokrasi, hak asasi manusia dan lingkungan hidup. ${ }^{21}$

2. Kesenjangan sosial, walaupun sudah menjalani perbaikan hidup karena kesenjangan sosial yang mencolok, suatu masyarakat dapat menjadi tidak puas, resah, cemburu dan akhirnya meledak dengan perilaku yang tidak terkendali sehingga dapat menghancurkan segi-segi positif dan keberhasilan usaha yang telah dicapai. Kesenjangan sosial lebih disebabkan oleh struktur sosial masyarakat daripada oleh perilaku perorangan yang dianggap bertanggungjawab atas terjadinya gejala tersebut. Kewaspadaan nasional terhadap berbagai kesenjangan sosial berkaitan langsung dengan kualitas nasionalisme. Nasionalisme masa kini adalah kebanggaan terhadap bangsa sendiri, harkatnya, martabatnya, kemunculannya semuanya itu dapat dicapai jika bangsa kita tidak lagi banyak yang miskin dan terbelakang. Demokrasi tidak akan hidup subur tanpa kesejahteraan dan keadilan sosial. Jangan kita mengabsolutkan dan mendewakan demokrasi. Demokrasi itu sendiri harus bergandengan, tidak boleh jalan sendiri dan mesti hidup bersama-sama dengan peningkatan kesehatan rakyat dan peningkatan keadilan sosial.

3. Masalah narkotika, peredaran narkotika di Indonesia semakin hari kian menghkawatirkan, karena itu Presiden Joko Widodo telah menyatakan bahwa Indonesia darurat narkoba sehingga kita harus terus melakukan perang terhadap narkotika. Bali sebagai destinasi pariwisata tidak luput dari semakin tingginya kasus narkotoika, bahkan public curiga di Bali ada pabriknya. Dugaan itu tidak berlebihan, karena sudah ratusan orang ditangkap dengan segudang barang bukti yang sudah diamankan, tetapi peredaran semakin menjadi-jadi bahkan sampai kepelosok-pelosok desa seperti di Desa Sidetapa, Sawan, Banyuatis dan banyak desa-desa lainnya hamper sudah memasuki semua kabupaten/kota di Bali. Keinginan sindikat narkotika di Bali untuk melakukan bisnis illegal tidak pernah surut. Karena itu Badan Nasional (BNN), Polri dan TNI harus terus memperkuat kerjasama/jaringan yang dibantu oleh peran serta masyarakat untuk melakukan penanggulangan dan pemberantasan tindak pidana narkotika. Menghadapi

\footnotetext{
${ }^{20}$ Djelantik S, (2010) Terorisme: Tinjauan Peiko-politis, Peran Media, Kemiskinan dan Keamanan Nasional, Yayasan Pustaka Obor Indonesia, Jakarta, h 256

${ }^{21}$ Ibid. h. 255
} 
ancaman bahaya narkotika di Bali sangat perlu melibatkan desa pekraman, yaitu dengan mengatur di dalam awig-awig maupun perarem di desa pakaraman.

4. Masalah korupsi, dalam perspektif hukum pidana, tindak pidana korupsi tergolong sebagai kejahatan yang sangat berbahaya, baik terhadap masyarakat maupun terhadap bangsa dan Negara. Kerugian keuangan Negara dan perekonomian Negara adalah akibat nyata yang menjadi alasan pembenar dilakukannya kriminalisasi terhadap berbagai bentuk perilaku koruptif dalam kebijakan perundang-undangan pidana. Akan tetapi berakibat hilangnya kepercayaan masyarakat terhadap pemerintah merupakan akibat yang jauh lebih besar dan lebih berbahaya daripada hanya sekedar kerugian dari sudut keuangan dan ekonomi semata $^{22}$. Karena itu Pemerintah, masyarakat sipil harus memilki komitmen yang kuat dan diwujudkan secara serius dan terus-menerus untuk melakukan penaggulangan dan pemberantasan tindak pidana korupsi.

5. Masalah teroris, Terorisme musuh semua kalangan yang memimpikan dan mencitacitakan perdamaian. Terorisme merupakan musuh Negara yang menyerang kedaulatan Negara dan keamanan masyarakat. Seluruh komponen bangsa harus terpanggil dalam upaya pencegahan terorisme. Terorisme merupakan musuh semua agama karena tidak ada satu pun agama yang mengajarkan kekerasan, kebrutalan. Terorisme tidak ada kaitannya dengan agama tertentu. Terorisme musuh semua Negara yang ingin mendambakan perdamaian dan ketertiban global. Karena itu kita harus tetap lawan radikalisme-terorisme.

6. Dekadensi moral, kondisi social bukanlah hal yang statis. Kuatnya arus materialism dan pendewaan benda dapat melumpuhkan kesadaran nilai-nilai moral yang seharusnya membentengi harkat dan martabat manusia. Oleh karena itu pembangunan moral, rokhani, dan spiritual harus berjalan seiring dengan kemajuan materiil agar terjadi keseimbangan hidup dalam kemantapan pribadi yang kokoh. Merosotnya moralitas seseorang berarti lunturnya penghargaan dan harga diri seseorang sebagai manusia. Lebih-lebih etika moral di kalangan generasi muda harus mendapat perhatian serius, pendidikan moral sangat diperlukan sejak usia dini, orang tua atau keluarga harus benar-benar memberikan perhatian kepada anak-anaknya apalagi menginjak usia remaja jangan sibuk dengan urusan sendirisendiri23, usahakan cukup waktu berkomunikasi dengan keluarga.

7. Apatisme dan ketidakpedulian sosial, perlu ditumbuhkan terus kesadaran bahwa hakikat pembangunan adalah untuk kepentingan manusia dan masyarakat, bukan sebaliknya manusia dan masyarakat untuk pembangunan, karena itu bagaimana menumbuhkan kepedulian sosial dengan sumber daya manusia yang maju dan berkualitas didukung oleh semangat kerja yang tinggi. Kerja bukanlah sekadar mencari nafkah dan untuk memenuhi kebutuhan sehari-hari, melainkan lebih jauh yaitu merupakan wujud aktualisasi diri dan wahana setiap orang untuk berprestasi dan mengembangkan bakat serta potensinya menjadi mahluk insane yang dewasa dan berguna bagi masyarakat. Karena itu sikap apatisme dan ketidakpedulian terhadap lingkungan maupun masyarakat juga menjadi perhatian pemerintah dengan etos kerja-kerja-kerja.

${ }^{22}$ Reksodiputro, M. (1998). Kemajuan Pembangunan Ekonomi dan Kejahatan. Pusat Pelayanan Keadilan dan Pengabdian Universitas Indonesia. Jakarta. h. 70

23Setiabudhi, I. K. R. (2016). Etika Moral Remaja di Ambang Kritis. Bali Post. Senin, 20 Juni 2016 
Berdasarkan beberapa uraian di atas dapat dilihat dengan jelas betapa luas rentangan kerawanan yang harus dicegah demi kuatnya persatuan dan kesatuan bangsa. Betapa luas dan mendalamnya kerawanan yang dapat di jumpai. Kita harus tetap punya komitmen yang tinggi untuk mengatasi kerawanan-kerawanan tersebut, agar tidak muncul lebih besar kepermukaan yang dapat membahayakan persatuan dan kesatuan bangsa.

\section{Kesimpulan}

Sikap radikal tidak selalu diimplementasikan dengan aksi kekerasan. Namun ada satu hal yang perlu mendapatkan perhatian adalah bahwa radikalisme selalu berhubungan dengan berbagai pandangan yang selalu dibedakan secara analitis karena proses radikalisme itu diarahkan oleh berbagai mekanisme yang berbeda, mengikuti beberapa pola yang berbeda, dan mesti dipahami dalam konteks sosio-politik lokal. Penyelenggaraan kewaspadaan dini masyarakat menjadi tanggung jawab dan dilaksanakan oleh masyarakat yang difasilitasi ataupun dibina oleh pemerintah provinsi, kabupaten/kota, kecamatan sampai dengan di tingkat desa. Membina dan memelihara ketenteraman, ketertiban dan perlindungan masyarakat; serta mengkoordinasikan tokoh masyarakat, tokoh adat, tokoh agama, tokoh pemuda, anggota satlinmas, anggota Polmas dan elemen masyarakat lainnya dalam kegiatan di bidang ketenteraman, ketertiban dan perlindungan masyarakat, dengan meningkatkan kewaspadaan dini masyarakat terutama di tingkat desa dan maupun kelurahan.

Desentralisasi dan otonomi daerah yang merupakan pilihan, karena ketika di masa lalu terasa pembangunan kurang merata, kurang adil, dan sentralistik. Kemudian kita analisis, kita lakukan pemberdayaan dan kita perbaiki sistem pemerintahan seperti itu, namun sekali lagi perlu ditegaskan jangan sekali sampai ikatan kesukuan, ikatan keagamaan, ikatan etnis, ikatan kedaerahan, dan ikatan-ikatan lainnya menabrak sendi-sendi ikatan kebangsaan yang harus tetap kita jaga dan kita pertahankan. Untuk hal itu, FKDM memiliki kunci yang penting guna dapat melakukan diteksi dini, sehingga hal-hal yang tidak kita inginkan muncul kepermukaan karena terlebih dulu sudah dapat dideteksi lebih awal oleh forum kewaspadaan dini masyarakat yang selanjutnya data dan informasi yang diperoleh segera dilaporkan kepada aparat yang berwenang.

Mengingat luas dan mendalamnya kerawanan di negara kita, maka kita harus berkomitmen untuk mengatasi kerawanan-kerawanan tersebut agar tidak muncul lebih besar kepermukaan yang dapat membahayakan persatuan dan kesatuan bangsa. Oleh karena itu peran dari Forum Kewaspadaan Dini Masyarakat harus dapat berfungsi secara efektif dan efisien dalam rangka menjaring, menampung, mengkoordinasikan dan mengkomunikasikan data dan informasi dari masyarakat mengenal potensi ancaman keamanan, gejala atau peristiwa bencana dalam rangka upaya pencegahan dan penanggulangan secara dini; dan memberikan rekomendasi sebagai bahan pertimbangan pemerintah mengenai kebijakan yang berkaitan dengan kewaspadaan dini masyarakat. Namun sangat disayangkan Forum Kewaspadaan Dini Masyarakat di Bali nampaknya belum berfungsi secara efektif, karena sejak pembentukannya sampai dengan saat ini sedikit bahkan ada yang belum pernah menyampaikan laporannya sesuai dengan bidang tugas dan fungsinya masing-masing wilayah. Karena itu kiranya keberadaan Forum Kewaspadaan Dini Masyarakat (FKDM) perlu dilakukan revitalisasi agar dapat berperan lebih maksimal. 


\section{Daftar Pustaka}

Buku

Malik, A. (2014). Diary Perdamaian: Mengenal, Mewaspadai, dan Mencegah Terorisme di Kalangan Generasi Muda. Jakarta: BNPT.

Marzuki, P. M. (2005). Penelitian Hukum. Jakarta: Prenada Media.

Reksodiputro, M. (1998). Kemajuan Pembangunan Ekonomi dan Kejahatan. Jakarta: Pusat Pelayanan Keadilan dan Pengabdian Universitas Indonesia.

Saifullah, S. (2015). Mengenal, Mewaspadai Mencegah Radikalisme dan Terorisme. Sumatera Barat: Forum Koordinasi Pencegahan Terorisme (FKPT).

Soekanto, S. \& Mamudji, S. (2004). Penelitian Hukum Normatif. Jakarta: Rajawali Pers.

Jurnal

Armawi, A. (2013). Kajian Penguatan Komunitas Intelijen Daerah. Mimbar HukumFakultas Hukum Universitas Gadjah Mada, 25(1), 68-75. https://doi.org/10.22146/jmh.16110

Ganor, B. (2002). Defining terrorism: Is one man's terrorist another man's freedom fighter? Police Practice and Research, 3(4), 287-304. https://doi.org/10.1080/1561426022000032060

Hikam, M. A. (2016). Pendidikan Multikultural dalam Rangka Memperkuat Kewaspadaan Nasional Menghadapi Ancaman Radikalisme di Indonesia. Global: Jurnal Politik Internasional. 17(1). 1-17. https://doi.org/10.7454/global.v17i1.26

Jazuli, A. (2017). Strategi Pencegahan Radikalisme dalam Rangka Pemberantasan Tindak Pidana Terorisme (Prevention Strategy of Radicalism in Order To Wipe Out The Terrorism Crime). Jurnal Ilmiah Kebijakan Hukum. 10(2). 197209. http://dx.doi.org/10.30641/kebijakan.2016.V10.197-209

Muin, F., \& Aspihanto, A. (2017). Sinergi Terhadap Pencegahan Terorisme dan Paham Radikalisme. Seminar Nasional Hukum Universitas Negeri Semarang. 3(1). 7390.

Mukhtar, S. (2016). Strategi Pemerintah Indonesia Menghadapi Terorisme dalam Era Demokratisasi. Reformasi. 6(2). 143-153.

Muladi, M. (2012). Hakekat Terorisme dan Beberapa Prinsip Pengaturan dalam Kriminalisasi. Jurnal Kriminologi Indonesia. 2(3). 1-13.

Mustofa, M. (2012). Memahami Terorisme: Suatu Perspektif Kriminologi. Jurnal Kriminologi Indonesia. 2(3). 30-38 
Prajarto, N. (2004). Terorisme dan media massa : Debat keterlibatan media. Jurnal Ilmu Sosial dan Ilmu Politik. 8(1). 37-52. https://doi.org/10.22146/isp.11057

Rajab, A. (2016). Urgensi Penguatan BNPT dalam Rangka Menjaga Keamanan dan Kedaulatan Negara. Jurnal RechtsVinding. 5(1). 1-15.

Sulistiono, I (2015) Peran Intelijen Keamanan dalam Melakukan Deteksi Dini Terhadap Perkembangan Gangguan Kamtibmas (Studi terhadap Penyelanggaraan Pilkada Di Kabupaten Ketapang tahun 2015). Jurnal nestor Magister Hukum, 1(1). 1-17.

Syukur, A. (2017). Gerakan Dakwah Dalam Upaya Pencegahan Dini Terhadap Penyebaran Dan Penerimaan Islamisme Kelompok Radikal-Terorisme Di Lampung. Analisis: Jurnal Studi Keislaman. 15(1). 219-250.

\section{Surat Kabar}

Setiabudhi, I. K. R. (2016). Etika Moral Remaja di Ambang Kritis, Bali Post. Senin, 20 Juni 2016. 